\title{
DIGITALCOMMONS
}

$10-1-2005$

\section{Faculty-Librarian Collaboration to Teach Research Skills: Electronic Symbiosis}

\author{
Navaz P. Bhavnagri \\ Wayne State University, nbhavna@wayne.edu \\ Veronica Bielat \\ Wayne State University, vbielat@wayne.edu
}

\section{Recommended Citation}

Bhavnagri, N. P. \& Bielat, V. (2005) Faculty-Librarian Collaboration to Teach Research Skills: Electronic Symbiosis, The Reference Librarian, 43(89-90): 121-138. DOI: 10.1300/J120v43n89_09

Available at: http://digitalcommons.wayne.edu/coe_ted/8 
NOTICE IN COMPLIANCE WITH PUBLISHER POLICY: This is a reconstructed and formatted version of a post print article originally published in The Reference Librarian, (43), 89-90, 2005, 121-138. Copyright @ 2005 by The Haworth Press, Inc. Archived by permission. Available online at: doi: 10.1300/J120v43n89_09 
Faculty-Librarian Collaboration

\title{
Faculty-Librarian Collaboration To Teach Research Skills: Electronic Symbiosis
}

\author{
Navaz P. Bhavnagri \\ Associate Professor \\ Early Childhood Education \\ Wayne State University \\ Detroit, Michigan 48202 \\ 313-577-0953 (Office) \\ 313-577-4091 (Fax) \\ Veronica Bielat \\ Information Services Librarian \\ Wayne State University \\ Detroit, Michigan 48202 \\ 313-577-4217 (Office) \\ 313-577-3436 (Fax)
}

Dr. Navaz Bhavnagri is an Associate Professor of Early Childhood Education in the College of Education at Wayne State University, 285 College of Education, Detroit, MI 48202 (e-mail:

nbhavna@wayne.edu).

Veronica Bielat is an Information Services Librarian and Liaison to the College of Education at Wayne State University, 134 Purdy Library, Detroit, MI 48202. (e-mail: vbielat@wayne.edu).

Abstract This article discusses faculty-librarian collaboration to integrate technology in a course that focuses on teaching empirical research methodologies and library research skills to elementary and early childhood education graduate students. Vygotsky's theory, standards in teacher education, and information literacy standards form the conceptual framework that supports this collaboration. The purpose and procedures of this collaboration, as well as student, faculty, and librarian outcomes, are discussed. This present collaboration on bibliographic instruction and the use of Blackboard 
Faculty-Librarian Collaboration

courseware is framed within the context of past history of collaboration and future plans to expand this collaboration.

Keywords Academic libraries, bibliographic instruction, collaboration, courseware, critical thinking, education students, faculty librarian relationship, information literacy, library research, technology

\section{FACULTY-LIBRARIAN COLLABORATION TO TEACH RESEARCH SKILLS: ELECTRONIC SYMBIOSIS}

Nesbitt states, "Preparing future teachers to meet information technology and research challenges requires the collaborative development of instructional strategies by both education faculty and academic librarians" (5). This article documents the collaboration between an education faculty member and academic librarian in providing instructional strategies on information technology and research skills for future and current teachers. This faculty-librarian electronic symbiosis took place in a course that focuses on research methodologies, offered to elementary and early childhood education master's level students in Wayne State University's (WSU) College of Education. One of the course objectives is for students to learn to access, analyze and synthesize information using library resources. Therefore, a library instruction session has always been included at the beginning of this course.

\section{CONCEPTUAL FRAMEWORK FOR COLLABORATION}

Mattessich and Monsey (Cook 23) define collaboration as a mutually beneficial undertaking to achieve common goals, supported by a well-designed structure. Our "common goal" is to have students achieve the course objectives stated above. The foundation of our "well designed collaborative structure" is first based on Vygotsky's conceptual framework of "scaffolding" and "zone of proximal development".

In Berk and Winsler $(26-27,171)$ and Bodrova and Leong $(42-43$, 162), scaffolding is described as a process by which individuals gradually learn with support, guidance, and direction from experts (such as adults or peers) until they finally work independently. In this collaborative effort, the librarian acts as expert, scaffolding the faculty member's skills in technology; the faculty member as an expert, scaffolding the librarian's knowledge of research and teaching pedagogy; and the faculty member and librarian (as peers), collaborating to scaffold student's research 
Faculty-Librarian Collaboration

methods, knowledge and skills. Finally, it is our contention that in addition to our actions as experts in the scaffolding process, technology can scaffold student learning because it is an expert educational tool that provides support and direction students need to learn, especially when the human expert (e.g., faculty or librarian) is not available to provide immediate assistance.

The zone of proximal development (ZPD) is a dynamic region between where an individual can accomplish independently to where a person can develop, learn and accomplish with assistance from a competent person (e.g., adult or peer) (Berk and Winsler 24-26 and Bodrova and Leong 34-47). This zone is an elastic area of development, which varies with the individual. The lower limit of ZPD demonstrates development that is achievable without intervention from a competent person or "expert", while the upper limit of ZPD demonstrates development of the student or "novice" with assisted performance (Wink and Putney 86). According to Vygotsky, when an expert (such as the faculty member or librarian) scaffolds a novice (such as the student) to the upper limit of ZPD, then it is a movement towards higher learning processes. Thus the new concepts which were first understood only within an inter-personal relationship between the expert and novice (i.e., lower ZPD) are finally becoming internalized and intra-personal, and the learner has now reached the level where they can work independently (i.e., upper ZPD).

Second, our collaborative structure is based on the WSU College of Education Conceptual Framework, guided by The National Council for Accreditation of Teacher Education (NCATE) Accreditation of Schools, Colleges, and Departments of Education professional standards (2002). The WSU Conceptual Framework states that it is a desirable outcome when "[the student] uses technology as an integral part of one's teaching and learning and is both a learner and a model of the use of technology in educational settings." (COE WSU).

Third, our collaborative structure is based on The American College and Research Library's (ACRL) Information Literacy Competency Standards for Higher Education. For this collaboration, we specifically focused on the ACRL Standard Two, namely the abilities to access needed information effectively and efficiently; Standard Three, namely the ability to critically evaluate information and sources and incorporate them into the student's knowledge base; and Standard Four, namely the ability to use information effectively to accomplish a specific purpose. These three standards parallel the intended outcomes stated in the course syllabus. 
Faculty-Librarian Collaboration

\section{PAST: \\ LIBRARIAN-FACULTY COLLABORATION AND TECHNOLOGY}

\section{History of Collaboration}

The following narrative discusses the changes in the library instruction process with the advent of technology, resulting in significant shifts in student participation and faculty-librarian collaboration. A decade ago, computers were not used in the library instruction for this course, since they were available only in public areas of the main floor of the library. Furthermore, there were few electronic databases available, and the librarians always mediated the students' searches. The librarian at that time provided printed handouts describing the complex computer search processes and lectured students on the mechanics of searching the ERIC database. The faculty member recollects that the students did not fully comprehend, retain or implement much of the information. Perhaps this was partly due to the method of delivery, and partly due to the students' unfamiliarity with computers.

As integration of technology into the library advanced, the librarian would then roll a computer into the classroom for the instruction session. Students would receive a lecture on search strategies, supplemented with handouts. The class would then gather around the single computer to view an active search. The students were excited, because they were now able to see a demonstration of a computer search by the librarian in real-time.

The faculty member was silent during these earlier phases of technology integration into the bibliographic instruction session. First, she was quiet because she viewed this to be the "librarian's turf," area of expertise, and to show respect to the librarian during her delivery. Second, she herself had limited computer skills. Third, there were no individual student computer stations for the faculty member to assist the librarian in supervising the students. Thus the collaboration between the faculty member and the librarian during instruction was minimal to non-existent.

The installation of computer labs in the library drastically shifted the teaching-learning process. Now the students in this course could simultaneously execute searches along with the librarian's demonstration. However, the bibliographic instruction session was still scripted. Namely, the students executed specific searches as prescribed by the librarian on a predetermined topic, but the students in class did not apply these generic scripted strategies to their own specific research question. Despite 
Faculty-Librarian Collaboration

it, the students were still elated because they could now participate in a hands-on activity using individual computers. The faculty member also began to actively collaborate in this teaching process, because for the first time there were multiple students' computer stations for her to monitor. The librarian and the faculty member thus began to communicate with each other about students' progress and problems.

Today, bibliographic instruction sessions take place in computer labs with interactive Smartboards, high-speed Internet networks and individual student workstations. The librarian now increasingly addresses the students individually by circulating among them for the following reasons. First, unlike before, the Smartboard allows her to move away from her demonstration workstation. Second, the students require even more individual attention now than before, given that the number of electronic resources available has increased substantially. Third, even though students today have more advanced computer skills than a decade ago, there is still a wide variation in their abilities, thus requiring individual attention.

The faculty member now collaborates with the librarian by being actively engaged in providing this well needed individualized guidance. Since the faculty member's knowledge and skills in technology have also increased over time, she is more confident to provide the necessary direct instruction and individualized supervision. Given the volume of library resources available and the complexity of the research process, bibliographic instruction has been expanded from a single session at the beginning of this fifteen-week course into two consecutive sessions. As a result, there is now time in class for students to apply the generic search strategies to their specific research questions, which students find very reassuring. The faculty member additionally collaborates with the librarian by providing her feedback on students' successes and failures in applying the library instruction in subsequent weeks. To summarize, growth in collaboration is due to an increase in technology, faculty member's expertise and her active engagement in instruction.

\section{PRESENT: \\ LIBRARIAN-FACULTY COLLABORATION AND TECHNOLOGY}

The collaborative effort in providing bibliographic instruction, and the development of a Blackboard course site, is described here within the Vygotskian framework. The following narrative is based on the faculty 
Faculty-Librarian Collaboration

member's journal of students' reactions to technology and her feedback; the librarian's recorded field notes on technological assistance to students and the faculty member; students' communications on Blackboard's discussion boards; and students' responses to an online survey, which was created and administered by the librarian and the faculty member. The students' responses to the survey provide anecdotal evidence of shifts in their ZPD. However, these responses have not been subjected to statistical scrutiny. This entire section is written from an outsider's perspective. First, we review the purpose for scaffolding. Next, we discuss the procedure for this collaborative process. Last, we examine the upper limit of librarian, faculty member and students' ZPD as outcomes of this collaboration.

\section{Bibliographic Instruction}

\section{Purpose: Scaffolding}

The bibliographic instruction scaffolded the students to reach several purposes.

Understand their electronic identity. According to Vygotsky, for novices to reach their upper ZPD, they often need experts scaffolding them verbally and experts performing actions on cultural tools, such as computers. Thus the librarian, who was the expert, verbally explained to the students, who were novices, the purpose and value of their electronic user ID and password identification. She further scaffolded them by her actions on the computer, when she demonstrated to them how to log on.

Results from the post-bibliographic instruction online survey indicated that more than $17 \%$ of the respondents did not even know their user ID, which is their "key" to electronic library and campus resources. Without this knowledge, these students would not be able to perform a myriad of tasks, e.g., access the electronic resources, the Blackboard courseware or their grades, or register for classes. Vygotsky states that conceptual understanding is only purposeful and valuable when it arises to answer a real problem within an actual social context (Harvey and Charnitski 152).

Develop a mental model of electronic library resources. The electronic library resources do not offer the same obvious visual tools and signs for structuring information that are readily apparent in paper-based indexes and card catalogs. Furthermore, most electronic databases are unique commercial products; therefore, the organization and display of 
Faculty-Librarian Collaboration

information can be very different between products, which further confounds the students' mental models of electronic data.

Students typically come to this course with a mental model of print media, or an inflexible and limited model of electronic media, all of which need "reshaping". Brandt says, "in order to teach effectively, librarians must understand users' mental models" (42). We further add, that the librarian must not simply "understand user's mental models" but also scaffold the students to revise their earlier mental model on information processing, to move them to the upper limit of their ZPD. For example, scaffolding students to develop mental models of a database, record fields and how the computer executes the search, in order to develop an effective search strategy. Thus, a mental model "is a complicated set of knowledge and beliefs which is used both as a source of referent understanding and as a tool for problem solving" (Brandt 42), which needs scaffolding by an expert such as a librarian.

Scaffold critical thinking skills. Murray, McKee and Hammons (107, 108) state that many graduate College of Education students are not competent in fully utilizing technology and doing independent library research for producing high quality research papers, despite living in an "information age". Our students in the master's program at Wayne State University also need to develop competency in producing high quality research papers, by developing critical thinking skills. These skills are at their lower ZPD and need scaffolding. According to Bodi, Ruggiero's third stage in teaching of critical thinking, namely the "investigation stage", is applicable to bibliographic instruction (70-71). Therefore, our students were first taught how to critically examine and investigate multiple sources in order to determine what kinds of sources would yield the most useful and relevant information. Both the librarian and the faculty member collaboratively introduced these discerning skills during the bibliographic instruction sessions, when the librarian assumed the role of expert.

During the semester, the role of expert was transferred to the faculty member, who actively taught these critical thinking skills throughout the semester. She used multiple scaffolding strategies such as role modeling, teaching the use of library resources to narrow their dependent and independent variables, teaching how to critique published research articles, and drafts of their research questions and hypothesis. Thus the students were scaffolded to develop higher-level skills in searching, identification and evaluation of research materials. 
Faculty-Librarian Collaboration

\section{Procedure: Collaborative Process}

The faculty member was present at both bibliographic instruction sessions. During these two instruction sessions, librarian, faculty member and students maintained an ongoing dialogue about search strategy, resource appropriateness, and scholarly research. For example, the librarian used both live search and a PowerPoint ${ }^{\circledR}$ presentation when introducing ERIC. Concurrently, the faculty member collaborated with the librarian by redefining library terminology, by verbally emphasizing resources and search methodology suggested by the librarian, and finally by reiterating important concepts stated by the librarian. Through this type of "verbal underlining" the faculty member communicated to the students that the librarian's messages had an "added value," a deeper meaning, and were relevant and applicable to the forthcoming course assignments. The librarian and faculty member thus equally participated in the delivery of information to develop information literacy skills in students. According to Vygotsky, knowledge was being co-constructed (developing joint knowledge by dialogue). Although the starting point and delivery of information may have differed, the information communication goals for both the faculty member and librarian were the same. Vygotsky calls this inter-subjectivity. The librarian and faculty member had voices in this communication process, during which "each communicant recognizes the echo of the original text [the information message] in the other's speech." (Kozulin 186).

Arp and Wilson (27) have developed structures of library instruction, identifying varying typologies of cooperation between the librarian and others. One of their structures is conceived as "Course Integrated Instruction". In this structure the bibliographic instruction becomes an integral part of the course because the "integration [of instruction] is usually achieved by discussion between faculty and librarians at the time the course is designed". It is this structure that best resembles our collaborative process. The faculty member's discussions with the librarian began in earnest when this graduate course was being redesigned to integrate computer technologies.

\section{Outcomes: Upper ZPD}

The electronic searches scaffolded students, the faculty member, and the librarian to reach higher mental processes at the upper limit of ZPD. 
Student. The goal of the bibliographic instruction sessions was to take the students from a lower level ZPD to an upper level ZPD, by attaining information literacy outcomes as described in the ACRL guidelines. When surveyed on skill self-assessment, $100 \%$ of the students reported their library search skills were better than when they had begun the class. In addition, $60 \%$ of the students reported that using the library resources facilitated their learning of research methods and concepts. The post-class survey dramatically provides a visual sense of their achievement, indicating their upper level of ZPD. For example, knowledge without assistance is reported in Figure 1. Knowledge with assistance is reported in Figure 2. The students believe that their level of expertise has increased after scaffolding.

FIGURE 1 - Student Survey Responses on ERIC Expertise Showing Lower Limit ZPD

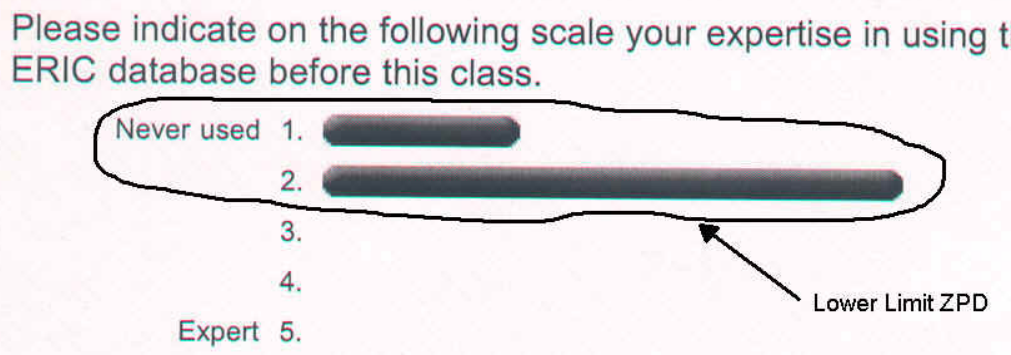

FIGURE 2 - Student Survey Responses on ERIC Expertise Showing Upper Limit ZPD

Please indicate on the following scale your expertise in using the ERIC database after this class.

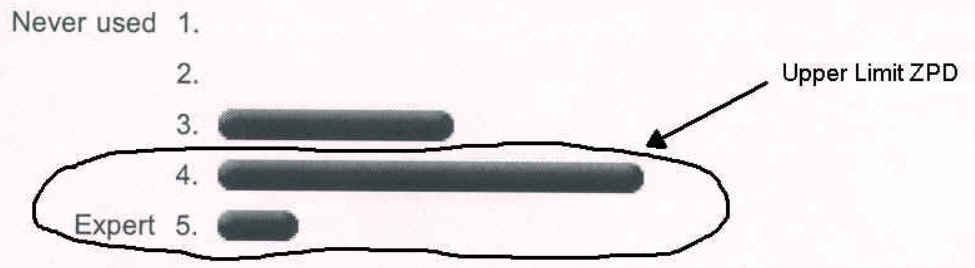

Faculty. This collaboration with the librarian enhanced the faculty member's awareness of new resources and strategies that are useful in personal research, thus moving her to the upper level of her ZPD. 
Faculty-Librarian Collaboration

Frequent social discourse about these searches with the librarian followed by self-reflection has increasingly expanded her zone, promoted interpersonal to intra-personal development, and further convinced her of the value of dialectic materialism. Her developmental shifts are similar to what Torres reported about teacher-researchers (2).

Librarian. This collaboration broadened the librarian's understanding of the faculty member's expectations of student outcomes on library assignments. This insight led to the development of handouts and a PowerPoint $\AA$ presentation on search strategies that have been effectively applied in bibliographic instruction for this course and other education courses.

\section{Blackboard}

\section{Purpose: Scaffolding}

Blackboard was employed by the faculty member in this course as a mediating strategy to scaffold students.

Self-instruction. The information available on Blackboard was to scaffold their learning at their own pace. Examples of self-instructional electronic scaffolds were: text chapter study guides, written instructions for each assignment, rubrics for self-evaluation, examples of previous students' exemplary assignments, and PowerPoint ${ }^{\circledR}$ presentations supporting each week's class content.

Promote peer teaching, communication and support. Student discussion boards were developed in Blackboard as communication tools. First, a class-wide discussion board was provided as a forum for peer teaching where students could suggest strategies on how to further refine their research questions and hypothesis. Second, discussion boards for group presentations on research methods were available to students, as a convenient $24 / 7$ alternative to face-to-face and telephone communications. For example: these were designed to save on phone bills, campus parking costs, travel time for face-to face meetings, and alleviate the difficulty of finding a common time to meet on campus. Finally, a discussion board was specifically designed to support and encourage students to ventilate their affect when learning about technology, because brain research clearly shows that affect can mediate cognition (Bergen and Cogcia). 
Faculty-Librarian Collaboration

\section{Procedure: Collaborative Process}

The development and maintenance of the Blackboard course site was the faculty member's responsibility. The librarian provided support to the faculty member in maintaining the course site throughout the semester, by constantly communicating via email, face-to-face and telephone conferencing, especially on Friday afternoons. The faculty member would share her vision and concept of what she would like in Blackboard and the librarian would respond, based on her technical expertise. A discussion would then follow as to other possibilities or pursuing the vision as stated.

Second, this collaborative effort on Blackboard was effective only because the faculty member and the librarian invested enormous amounts of time, energy and effort, which resulted in successes, but also many false starts of undoing and redoing the postings to Blackboard. At other times, they had to call on other experts, such as faculty and staff of curriculum and technology, to scaffold them in the knowledge and skills required to achieve their stated goal. Thus, this kind of true collaborative effort involves juggling one's ongoing myriad of responsibilities, being disciplined, balancing the workload, and creating a flexible schedule (Winner 27-28). Regardless of how onerous a task it may seem, multiple scholars (e.g., Cook 25, Cardwell 257, Zhang 141) have reiterated that faculty-librarian collaboration is a worthwhile endeavor because it significantly contributes to the librarian's professional development.

Third, this collaboration on the development of the Blackboard course site was a symbiotic relationship because the faculty member and the librarian had complimentary expertise. The faculty member had content knowledge of information, and the librarian had the necessary technological skills. For example, the faculty member had published in electronic journals but did not know how to link her articles to the Blackboard site. This was made possible by the librarian's expertise. The librarian also taught the faculty member how to make the documents available in multiple formats to enhance and simplify student access. The faculty member and the librarian continued to share different skills and knowledge as the collaboration progressed.

Fourth, the faculty member and librarian collaborated to teach students how to access the Blackboard course site. Even though over $80 \%$ of students knew their WSU access ID at the beginning of the class, many of them had difficulty logging on to Blackboard, and accessing and downloading course materials. While the faculty member gave a tour of the Blackboard site to the entire class, the librarian provided individual assistance to students experiencing difficulty in accessing the courseware. 
Faculty-Librarian Collaboration

This strategy of the group touring the courseware along with individualized support from the librarian is imperative, as it is insufficient to merely announce to students that there is a Blackboard site available for the course and to expect them to fully utilize it as a scaffolding tool. Just as the syllabus needs reviewing in detail at the beginning of a course, so does the Blackboard course site.

\section{Outcomes: Upper ZPD}

The use of Blackboard scaffolded the students, the faculty member, and the librarian to reach higher mental processes at the upper limit of ZPD.

Student. First, access to the materials on Blackboard was selfinstructional to move to the upper limit of their ZPD. Kuhlthau's stage model has identified that students feel apprehension, uncertainty, confusion and anxiety when tackling research assignments (237-240). These negative affects impede student progress in reaching their upper limit of ZPD. Easy access to materials on Blackboard counteracted this phenomenon. Using the courseware, the faculty member mounted several sample assignments for student reference. As a result, the faculty member observed that students demonstrated more confidence by submitting more criticality in their reviews of research literature. They did not repeatedly ask for clarification of assignment details, as students have typically done in the past, thus demonstrating less anxiety about their performance. Finally, the availability of a textbook study guide on Blackboard enhanced student comprehension.

Second, it was most effective in promoting communication and support as evidenced by survey responses (See Figure 3 - Student Responses to Survey Questions 11 and 12), but less so in peer teaching. Students used the Blackboard discussion boards early in the semester to successfully communicate their research question and hypothesis. However, students did not take the risk of teaching by improving on their peer's hypothesis. By the end of the semester, a few students had moved to an upper level of their ZPD in peer teaching by suggesting improvements to their peers' research question and/or hypothesis. The discussion boards served the overall purpose of promoting peer communication. Through their design, and by being based on the Vygotskian premise, they advanced collective knowledge, communication and support, which in turn led to individual's gaining knowledge and confidence, and reducing students' uncertainty and anxiousness (Hung and Nichani 5). 
Faculty-Librarian Collaboration

\section{FIGURE 3 - Student Responses to Survey Questions 11 and 12}

The course instructor believed the group presentation discussion board would be of service to students in the following ways. Please

11. select which of the following applies to you (select all that apply):

I did not use the group presentation discussion board

To facilitate communication between you and your fellow group members

To facilitate a helping relationship across the members of the

Tuesday \& Thursday sections

To read comments from research method groups other than your own and learn from it

To communicate progress to and receive feedback from the instructor

To provide the instructor with the necessary details before she has

a face-to-face conference with group members

Other
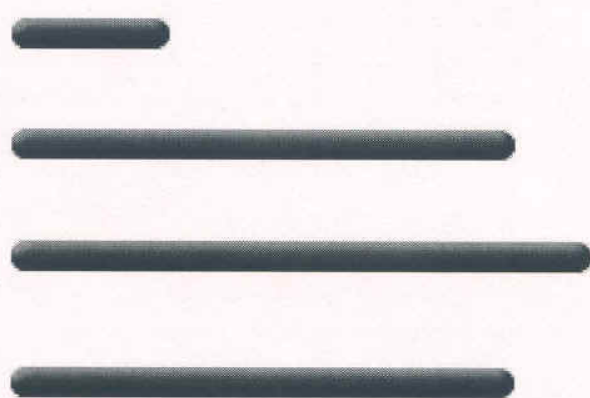

If you did use the group presentation discussion board, please select the types of information you communicated with other group

12. members (you may select more than one).

To communicate and confirm dates for group meetings

to list books and resources (e.g. artifacts) found for presentation

To communicate your understanding or lack of understanding of the concepts your group was planning to teach

To express time concerns about

the presentation

To express emotions about the presentation

Other

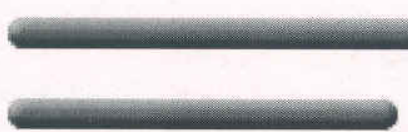

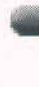
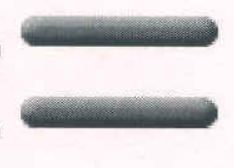
Faculty-Librarian Collaboration

A special discussion board was designed for student's emotional catharsis and for them to vent the challenges they faced in using the technology. We found that it actually provided a forum beyond catharsis, to resolution of the problems that confronted them. Students who were "experts" in technology communicated to "novices" the relevant strategies regarding resolving technology problems, thus moving the "novices" to the upper limit of their ZPD. Providing this avenue for self-expression of emotions appeared to reduce their overall frustration over technology, and freed them to focus on higher cognitive processing.

Faculty. First, Blackboard scaffolded the faculty member to know students as individuals and build her relationship with them, especially those students who typically did not talk in class but felt comfortable communicating with her via Blackboard. Additionally, by reading their communications to each other, she knew their concerns and could steadily monitor individual progress.

Second, Blackboard scaffolded the faculty member to teach and monitor students' group presentations. For example: she came to know of each individual member's contribution to the group; she monitored their process of decision-making by complimenting and redirecting them with specific suggestions; and she was better prepared when the students shared their plans about their group presentations, resulting in shorter conferences. The discussion boards in Blackboard made the faculty member more available between class sessions. This availability, in turn, increased her opportunities to be more effective in relationship building, teaching, and monitoring, thus moving her to the upper limit of her ZPD.

Librarian. The development of the Blackboard course site scaffolded the librarian by expanding her knowledge of course content, particularly the six research methods. The librarian, by working with the faculty member, better understood how to incorporate an electronic component, such as Blackboard, into teaching pedagogy. Finally, the librarian was regularly able to gain knowledge about students' abilities and difficulties, and discover areas in the delivery of library instruction that needed revision. This was a direct result of her access to the student discussion boards. 
Faculty-Librarian Collaboration

\section{FUTURE: \\ LIBRARIAN-FACULTY COLLABORATION AND TECHNOLOGY}

In this section we discuss plans for future collaborations in providing bibliographic instruction and further enhancing the Blackboard course site.

\section{Bibliographic Instruction}

Develop Instructional and Evaluative Materials

We plan to design two instructional materials. First, we will develop a PowerPoint $\AA$ presentation on critical thinking skills in evaluating library sources. This presentation will contain samples of available electronic documents and journals collaboratively selected by the librarian and the faculty member. Students will be able to immediately connect their new evaluative skills with appropriate examples. This co-teaching is designed on Bodi's recommendations $(1992,72)$ that students' critical thinking skills for evaluating sources can be best enhanced when librarians and faculty are instructing collaboratively and in unison.

Second, we plan to develop an interactive instructional electronic worksheet where students systematically record appropriate database search strategies. The purpose of this worksheet is for students to selfevaluate their ability to apply what is taught in class; and for us to find out which specific strategies are unclear to them, so that we may revisit them in the next session. The ACRL's Education and Behavioral Sciences Section Bibliographic Instruction for Educators Committee recommended that such a worksheet with instructions for ERIC and blanks for strategy formulation would be a desirable tool for teaching information retrieval and evaluation skills (ACRL 588).

We also plan to design two sets of evaluative materials. The first is a revision of the rubric used to evaluate students' electronic search journals. The faculty member unilaterally designed the current rubric but the future rubric will be collaboratively constructed. Furthermore, the revised rubric will be based on information literacy standards and the conceptual framework of the WSU College of Education, which addresses the NCATE standards. Second, we will develop and administer a quiz through Blackboard after the bibliographic instruction sessions. This quiz will be designed on Cudiner and Harmon's (1) suggestions for promoting active learning in students; and on Brandt's recommendation to identify 
Faculty-Librarian Collaboration

learners' existing mental models of information organization and retrieval in order to provide a matching teaching strategy for information literacy.

\section{Role Meshing}

Cardwell $(254,255)$ advises that to truly facilitate student learning, the librarian must also act as an instructor. We believe that for this course, the faculty member must also act as a reference librarian. Therefore, in the future, the faculty member will be available in the library during her office hours in the weeks immediately following the bibliographic instruction sessions, to guide students with their library research. In the future, the librarian will be an instructor electronically. This will be accomplished through the development of a separate librarian discussion board in Blackboard. This discussion board will thus send an explicit message to the students that the librarian is an instructor who is accessible throughout the semester, and her availability is not limited to the two bibliographic instruction sessions.

\section{Blackboard}

\section{Photographic Instruction}

Most students enrolled in this course are newly admitted into the master's program and are therefore unfamiliar with the vast library resources available. Hence, we plan to mount floor maps in Blackboard of various locations in the library with digital photographs of: circulation, reference and reserved material desks; separate stacks for journals and books; area for displaying the recent journals; inter-library loan services; microfiche research area, and main floor computer area. We anticipate that this self-instructive electronic walking tour of the library will help students feel less overwhelmed when they have to go to the library to access materials.

\section{Video Instruction}

We will upload video clips demonstrating students' exemplary presentations on research methods. For example: role-playing and conducting interviews and focus groups; coding video taped observations; and analyzing artifacts and documents for case studies, and ethnographic and historical research. These videos will be enhanced by written products related to these clips such as: interview protocol, focus group discussion 
Faculty-Librarian Collaboration

guide, observation coding system, matrix for analyzing the artifacts for a case study, a webbing chart indicating triangulation of data in ethnography, and a rubric for historical criticism of documents. There are two purposes for these exhibits: first, to facilitate teaching students to visualize how to plan, conduct and evaluate their constructivist group presentations, and second, for the faculty member to explain the rubric used for evaluating their group presentations.

\section{CONCLUSION}

Our narrative has described how our collaborative effort evolved, and we expect our collaboration to continue from an interpersonal to synergetic level (Raspa and Ward). According to Raspa and Ward, the interpersonal level of a collaboration is where "the partners begin to explore both personal and interdisciplinary areas of interest, and may undertake small projects" (12). We began this collaboration by exploring our "personal and interdisciplinary areas of interest" and undertook bibliographic instruction and integration of Blackboard as our "small project" for a course focusing on research methods.

We believe we have moved into the beginnings of the synergetic level, which means "the boundaries separating the disciplines begin to blur" (Raspa and Ward 13). Our role boundaries as librarian and faculty have already been blurred as documented in our present collaboration, and the process of writing this article in a collaborative manner has further advanced us to a synergetic level. Our future plans documented in this article further blurs our roles, resulting in a seamless delivery of course content to our students. Our vision is of continuous long-term collaboration that sustains this high level of synergy, which will result in even more effective outcomes benefiting all learners--faculty, librarians and students. 
Faculty-Librarian Collaboration

WORKS CITED

Arp, Lori, and Lizabeth A. Wilson. "Structures of Bibliographic Instruction Programs: A Continuum for Planning." Reference Librarian 24 (1989): 25-34.

Association of College \& Research Libraries. Education and Behavioral Sciences Section. Bibliographic Instruction for Educators Committee (1991-1992). "Information retrieval and evaluation skills for education students." C\&RL News 9 (1992): 583-588.

Association of College \& Research Libraries. Information Literacy Competency Standards for Higher Education: Standards, Performance Indicators, and Outcomes. Chicago: ACRL, 2000. 4 March 2003 <http://www.ala.org/acrl/ilstandardlo.html>.

Bergen, Doris and Juliet Coscia. Brain Research and Childhood Education: Implications for Education. Olney MD: ACEI, 2001.

Berk, Laura E., and Adam Winsler. Scaffolding Children's Learning: Vygotsky and Early Childhood Education. NAEYC Research into Practice Ser. 7. Washington: NAEYC, 1995.

Bodi, Sonia. "Collaborating with Faculty in Teaching Critical Thinking: The Role of Librarians." Research Strategies 102 (1992): 69-76.

Bodrova, Elena, and Deborah J. Leong. Tools of the Mind: The Vygotskian Approach to Early Childhood Education. Englewood Cliffs:

Prentice-Hall, 1996.

Brandt, D. Scott. "Reference, Mental Models and Teaching Technology." The Reference Librarian 74 (2001): 37-47.

Cardwell, Catherine. "Faculty: An Essential Resource for Reference Librarians. At Bowling Green State University." The Reference Librarian 73 (2001): 253-63.

College of Education, Wayne State University. Conceptual Framework Report. Detroit: COE WSU. 5 April 2003. <http://www.coe.wayne.edu/conceptual_framework.htm>.

Cook, Doug. "Creating Connections: A Review of the Literature." The Collaborative Imperative: Librarians and Faculty Working Together in the Information Universe. Ed. Richard Raspa and Dane Ward. Chicago: ACRL, 2000. 19-38.

Cudiner, Shelley, and Oskar R. Harmon. "An Active Learning Approach to Teaching Effective Online Search Strategies: A Librarian/Faculty Collaboration." T.H.E. Journal 28.5 (2000): 52-7.

Harvey, Francis A. and Christina Wodell Charnitski. "Improving Mathematics Instruction Using Technology: A Vygotskian Perspective." ERIC, 1998. ED 423837. 
Faculty-Librarian Collaboration

Hung, David Wei Loong and Maish Nichani. "Bringing Communities of Practice Into Schools: Implications for Instructional Technologies From Vygotskian Perspectives." International Journal of Instructional Media 29 (2002): 171-183.

Kozulin, Alex. Vygotsky's Psychology: A Biography of Ideas. New York: Harvester Wheatsheaf, 1990.

Kuhlthau, Carol C. "Developing a mental model of the library search process: Cognitive and affective aspects." RQ 28 (1988). 232-242.

Murray, Jr., John W., Elizabeth Chadbourn McKee and James O. Hammons. "Faculty and Librarian Collaboration: The Road to Information Literacy for Graduate Students." Journal on Excellence in College Teaching 8 (1997): 107-121.

National Council for Accreditation of Teacher Education. Professional Standards for the Accreditation of Schools, Colleges, and Departments of Education. Washington: NCATE, 2002. 4 March $2003<$ http://www.ncate.org/2000/unit_stnds_2002.pdf>.

Nesbitt, Renee. "Faculty-Librarian Partnerships." Education Libraries 21 (1997): 5-11.

Raspa, Richard, and Dane Ward. "Listening for Collaboration: Faculty and Librarians Working Together." The Collaborative Imperative: Librarians and Faculty Working Together in the Information Universe. Ed. Richard Raspa and Dane Ward. Chicago: ACRL, 2000. 1-18.

Torres, Myriam N. "Teacher-Researchers in the 'Zone of Proximal Development': Insights for Teacher Education." ERIC, 1996. ED 410189.

Vygotsky, Lev Semenovich. Thought and language. Trans. Eugenia Hanfmann and Gertrude Vakar. Cambridge: MIT P, 1962.

Wink, Joan, and LeAnn Putney. A Vision of Vygotsky. Boston: Allyn and Bacon, 2002.

Winner, Marian C. "Librarians as Partners in the Classroom: An Increasing Imperative." Reference Services Review 26 (1998): 25-30.

Zhang, Wenxian. "Building Partnerships in Liberal Arts Education: Library Team Teaching." Reference Services Review 29 (2001): 141-149. 